\title{
Dispersion Stability of Supported Palladium Crystallites
}

\author{
Seishiro Nakamura*1) and Henry Wise*2)
}

\begin{abstract}
The dispersion stability of supported Pd has been studied over a range of temperatures. The results of this study demonstrated that the initial dispersion of $\mathrm{Pd}$ crystallites on $\mathrm{Al}_{2} \mathrm{O}_{3}$ was much larger than on $\mathrm{SiO}_{2}$ or on $\mathrm{SiO}_{2} / \mathrm{Al}_{2} \mathrm{O}_{3}$ when prepared by wet impregnation method. The metal on the $\mathrm{Al}_{2} \mathrm{O}_{3}$ support was more resistant to thermal sintering in vacuum. These differences were due to the chemical interactions of the support with the reduced Pd metal or the $\mathrm{Pd}$ salt used in the catalyst preparation. The degree of thermal sintering of $\mathrm{Pd} / \mathrm{Al}_{2} \mathrm{O}_{3}$ in vacuum was found to depend on the fractional surface coverage of the carrier with Pd (FSC). The small crystallites were stabilized at low FSG, i.e., on a carrier with a high surface area and low Pd loading.

The degree of the crystallite growth of Pd in hydrogen or in oxygen atmosphere was similar to that in vacuum. On the other hand, the pronounced crystallite growth of Pd was observed in the presence of acetic acid/oxygen mixtures at considerably lower temperatures. The aggregation of $\mathrm{Pd}$ under such conditions was associated with the formation of palladous acetate and its migration on the surface of catalysts.
\end{abstract}

\section{Introduction}

Loss in the metal surface area of supported catalysts due to thermal sintering remains a problem of considerable importance in catalyst technology. While the subject has received a great deal of attention in the past, the development of surface-reactive methods for metal surface area determination by surface titration of the chemisorbed oxygen by either hydrogen ${ }^{1)}$ or carbon monoxide ${ }^{2), 3)}$ provides the opportunity for quantitative measurements, especially at high levels of metal dispersion where alternate experimental techniques with supported metal catalysts are more difficult.

With supported Pt-catalysts ${ }^{4) ~ 15)}$ the temperature and gaseous environments have a profound influence on the rate of sintering. In addition, the type of insulator support employed, the metal weight loading, the method of catalyst preparation and the length of exposure to elevated temperatures affect the crystallite size distribution attained on the catalyst.

For supported Pd-catalysts fewer data are available ${ }^{17) ~ 20)}$. By means of the surface titration of the chemisorbed oxygen with $\mathrm{CO}$, reported earlier for $\mathrm{Pt}^{2}$ ) and $\mathrm{Pd}^{3}$ ), a detailed sintering study was

Received April 11, 1979.

*1) Central Research Laboratories, Kuraray Co., Ltd. (2045-1, Sakazu, Kurashiki, Okayama, Japan).

*2) Solid State Catalysis Laboratory, SRI International, (Menlo Park, GA 94025, USA). undertaken in order to further the development of thermally stable $\mathrm{Pd}$ metal dispersion.

\section{Experimental Details}

The catalysts were prepared by conventional wet impregnation technique. A number of $\mathrm{Al}_{2} \mathrm{O}_{3}$, $\mathrm{SiO}_{2}$ and $\mathrm{SiO}_{2} / \mathrm{Al}_{2} \mathrm{O}_{3}$ supports were impregnated with an aqueous solution of sodium tetrachloropalladate to yield the desired weight loading of the metal. After evaporation to dryness on a steam bath, the samples were reduced with an alkaline solution of hydrazine hydrate $\left(5 \mathrm{wt} \% \mathrm{~N}_{2} \mathrm{H}_{4}, 1-N\right.$ $\mathrm{NaOH}$ solution), washed with distilled water until free of $\mathrm{Cl}^{-}$ion, then dried under reduced pressure (20 torr) at $60^{\circ} \mathrm{C}$ for 10 hours.

All carriers were obtained from commercial sources (Table 1). Preceding the surface area determination, the supported Pd-catalysts were crushed and screened (14 20 mesh).

The surface area of each carrier was measured by means of the BET method(Kr). Pore volume distribution was determined by high pressure mercury porosimetry. Analogous to the earlier work, the Pd surface area was determined by "surface titration" involving the interaction of oxygen adatoms on Pd-sites with gaseous carbon monoxide, and quantitative determination of the mass of carbon dioxide produced $(\mathrm{O}(\mathrm{s})+2 \mathrm{CO} \rightarrow \mathrm{CO}(\mathrm{s})+$ $\left.\mathrm{CO}_{2}\right)^{2), 3)}$. The measurements were carried out in an electrically heated quartz reactor into which the sample under study could be introduced and exposed to various temperatures for various time 
Table 1 Physical Structure of Catalyst Support

\begin{tabular}{lcccl}
\hline Carrier No. & $\begin{array}{c}\mathrm{S} . \mathrm{A} . \\
\left(\mathrm{m}^{2} / \mathrm{g}\right)\end{array}$ & $\begin{array}{c}\text { Pore Volume } \\
(\mathrm{cc} / \mathrm{g})\end{array}$ & $\begin{array}{c}\text { Pore Size } \\
\text { Distribution } \\
(\AA) *\end{array}$ & Source \\
\hline $\mathrm{Al}_{2} \mathrm{O}_{3}$ (I) & 150 & - & $<100$ & $\begin{array}{l}\text { Mallinckrodt Chem. Co. } \\
\mathrm{Al}_{2} \mathrm{O}_{3} \text { (II) }\end{array}$ \\
$\mathrm{Al}_{2} \mathrm{O}_{3}$ (III) & 82 & 0.35 & $120 \sim 160$ & Mizusawa Chem. Co. \\
$\mathrm{Al}_{2} \mathrm{O}_{3}$ (IV) & 23 & 0.30 & $200 \sim 500$ & Mizusawa Chem. Co. \\
$\mathrm{Al}_{2} \mathrm{O}_{3}$ (V) & 9 & - & broad & Mallinckrodt Chem. Co. \\
$\mathrm{Al}_{2} \mathrm{O}_{3}$ (VI) & 9 & 0.29 & $600 \sim 1,500$ & Shokubai Kasei Co. \\
$\mathrm{SiO}_{2}(\mathrm{I})$ & 8 & 0.27 & $1,400 \sim 1,700$ & Mizusawa Chem. Co. \\
$\mathrm{SiO}_{2}$ (II) & 96 & 0.61 & $37.5 \sim 300$ & Nikki Chem. Co. \\
$\mathrm{SiO}_{2}$ (III) & 105 & 1.09 & $100 \sim 300$ & Nikki Chem. Co. \\
$\mathrm{SiO}_{2} \cdot \mathrm{Al}_{2} \mathrm{O}_{3}$ & 25 & - & $37.5 \sim 700$ & Nikki Chem. Co. \\
\hline
\end{tabular}

$* 80 \%$ of total pore volume.

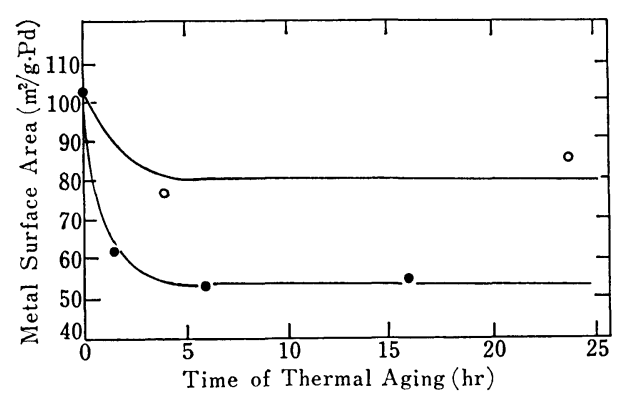

Catalyst : $\mathrm{Pd} 1.0 \mathrm{wt} \%-\mathrm{Al}_{2} \mathrm{O}_{3}$ (III)

Thermal aging in vacuum : $\bigcirc 250^{\circ} \mathrm{C}$, $600^{\circ} \mathrm{C}$

Fig. 1 Effect of Temperature on Sintering

periods. The reactor, an integral part of the apparatus employed for surface-area measurement, could be evacuated $\left(\mathrm{P}<10^{-6}\right.$ torr $)$ and filled with different gases at any desired pressures. Following such treatment the catalyst sample could be subjected to the surface-area titration without the intervening exposure to room air. The mean crystallite size was calculated from the Pd surface area and Pd content ${ }^{11)}$.

\section{Results}

\subsection{Sintering in Vacuum}

The role of the catalyst support on the sintering of Pd-crystallites was investigated in a series of experiments in which individual samples were exposed to elevated temperatures for fixed periods of time in vacuum $\left(\mathrm{P}<10^{-6}\right.$ torr $)$. At any prescribed time interval the surface area of the sample was determined. A representative example of the sintering behavior of the $\mathrm{Pd} / \mathrm{Al}_{2} \mathrm{O}_{3}$ (III) catalyst at several temperatures is shown in Fig. 1. To obtain information of the effect of different $\mathrm{Al}_{2} \mathrm{O}_{3}$ support materials on the sintering process the data summarized in Fig. 2 were collected. In each of these samples the Pd-content was $1 \mathrm{wt} \%$. On varying the weight loading of $\mathrm{Pd}$ from 1.0 to 0.1

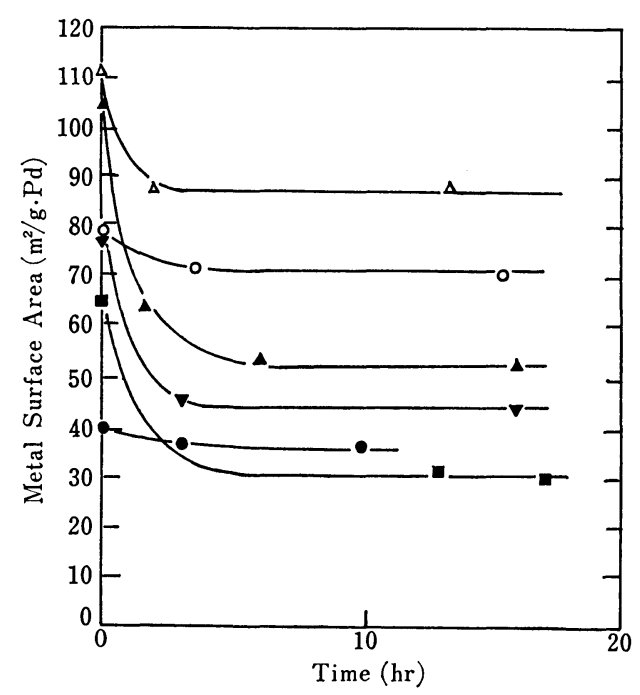

Catalyst : $\mathrm{Pd} 1.0 \mathrm{wt} \%-\mathrm{Al}_{2} \mathrm{O}_{3}$ $\triangle \mathrm{Al}_{2} \mathrm{O}_{3}(\mathrm{I}), \bigcirc \mathrm{Al}_{2} \mathrm{O}_{3}(\mathrm{II}), \boldsymbol{\Delta} \mathrm{Al}_{2} \mathrm{O}_{3}(\mathrm{III})$, $\nabla \mathrm{Al}_{2} \mathrm{O}_{3}(\mathrm{IV}), \mathrm{Al}_{2} \mathrm{O}_{3}(\mathrm{~V}), \square \mathrm{Al}_{2} \mathrm{O}_{3}(\mathrm{VI})$.

Heat treatment : $600^{\circ} \mathrm{C}$ in vacuum

Fig. 2 Effect of Carrier Type $\left(\mathrm{Al}_{2} \mathrm{O}_{3}\right)$ on Sintering

$\mathrm{wt} \%$ on $\mathrm{Al}_{2} \mathrm{O}_{3}(\mathrm{IV})$ a marked decrease in sintering rate was observed (Table 2). At the lowest Pdloading $(0.1 \mathrm{wt} \%)$ no change in the total metal surface area was observed after exposure to vacuum at $600^{\circ} \mathrm{G}$ for 17 hours (Fig. 3).

With silica and silica-alumina supports, the initial Pd dispersion was found to be much smaller than that observed for the aluminas (cf. Tables 2 and 3). Also on these carriers the metal appeared to be less resistant to sintering.

\subsection{Sintering in Chemically Reactive Atmos- pheres}

In extending the studies on thermal sintering in vacuum, the effect of chemically reactive gases, hydrogen, oxygen and acetic acid (in air), on the stability of the Pd-dispersion was examined. The results, summarized in Table $\mathbf{5}$, demonstrate a relatively small contribution of $\mathrm{H}_{2}$ or $\mathrm{O}_{2}$ to crystal- 
Table 2 Effect of Palladium Content on Thermal Sintering at $600^{\circ} \mathrm{C}$

\begin{tabular}{|c|c|c|c|c|c|c|}
\hline \multicolumn{2}{|c|}{ Carrier } & \multirow{2}{*}{$\begin{array}{l}\text { Pd Content } \\
(\mathrm{wt} \%)\end{array}$} & \multirow{2}{*}{$\begin{array}{c}\text { Heat } \\
\text { Treatment } \\
\text { (hr) }\end{array}$} & \multirow{2}{*}{$\begin{array}{c}\mathrm{S} \cdot \mathrm{A} \\
\left(\mathrm{m}^{2} / \mathrm{g} \mathrm{Pd}\right)\end{array}$} & \multirow{2}{*}{$\begin{array}{l}\text { Pd Crystal } \\
\left.\text { Size }(\AA)^{* 1}\right)\end{array}$} & \multirow{2}{*}{$\begin{array}{l}\text { Fractional Surface*2) } \\
\text { Coverage of Carrier } \\
\text { with Pd }(\%)\end{array}$} \\
\hline No. & $\begin{array}{c}\text { S.A. } \\
\left(\mathrm{m}^{2} / \mathrm{g}\right)\end{array}$ & & & & & \\
\hline \multirow{2}{*}{$\mathrm{Al}_{2} \mathrm{O}_{3}$} & \multirow{2}{*}{82} & 1.0 & $\begin{array}{c}0 \\
3.5 \\
15.5\end{array}$ & $\begin{array}{l}79 \\
71.5 \\
70\end{array}$ & $\begin{array}{l}63 \\
70 \\
71.5\end{array}$ & $\begin{array}{l}0.24 \\
0.22 \\
0.21\end{array}$ \\
\hline & & 5.0 & $\begin{array}{r}0 \\
3 \\
16\end{array}$ & $\begin{array}{l}59 \\
37 \\
34\end{array}$ & $\begin{array}{r}85 \\
135 \\
147\end{array}$ & $\begin{array}{l}0.90 \\
0.57 \\
0.53\end{array}$ \\
\hline \multirow{2}{*}{$\mathrm{Al}_{2} \mathrm{O}_{3}(\mathrm{~V})$} & \multirow{2}{*}{9} & 0.3 & $\begin{array}{r}0 \\
3 \\
10\end{array}$ & $\begin{array}{l}61 \\
56 \\
54\end{array}$ & $\begin{array}{l}82 \\
89 \\
92.5\end{array}$ & $\begin{array}{l}0.51 \\
0.46 \\
0.45\end{array}$ \\
\hline & & 1.0 & $\begin{array}{r}0 \\
3 \\
10\end{array}$ & $\begin{array}{l}40 \\
36 \\
36\end{array}$ & $\begin{array}{l}125 \\
139 \\
139\end{array}$ & $\begin{array}{l}1.1 \\
1.0 \\
1.0\end{array}$ \\
\hline \multirow{3}{*}{$\mathrm{Al}_{2} \mathrm{O}_{3}$ (IV) } & \multirow{3}{*}{9} & 0.1 & $\begin{array}{r}0 \\
17\end{array}$ & $\begin{array}{l}97.5 \\
99\end{array}$ & $\begin{array}{l}51 \\
50.5\end{array}$ & $\begin{array}{l}0.271 \\
0.275\end{array}$ \\
\hline & & 0.3 & $\begin{array}{l}0 \\
2.5 \\
16\end{array}$ & $\begin{array}{l}99 \\
69 \\
73\end{array}$ & $\begin{array}{l}50.5 \\
72.5 \\
68\end{array}$ & $\begin{array}{l}0.825 \\
0.575 \\
0.61\end{array}$ \\
\hline & & 1.0 & $\begin{array}{r}0 \\
3 \\
16\end{array}$ & $\begin{array}{l}78 \\
43 \\
44\end{array}$ & $\begin{array}{r}64 \\
116 \\
114\end{array}$ & $\begin{array}{l}2.2 \\
1.2 \\
1.2\end{array}$ \\
\hline \multirow{2}{*}{$\mathrm{Al}_{2} \mathrm{O}_{3}(\mathrm{VI})$} & \multirow{2}{*}{8} & 0.3 & $\begin{array}{r}0 \\
3 \\
17\end{array}$ & $\begin{array}{l}91 \\
74.5 \\
63\end{array}$ & $\begin{array}{l}55 \\
67 \\
79.5\end{array}$ & $\begin{array}{l}0.85 \\
0.70 \\
0.59\end{array}$ \\
\hline & & 1.0 & $\begin{array}{r}0 \\
13 \\
17\end{array}$ & $\begin{array}{l}65 \\
32 \\
29\end{array}$ & $\begin{array}{r}77 \\
156 \\
173\end{array}$ & $\begin{array}{l}2.0 \\
1.0 \\
0.9\end{array}$ \\
\hline
\end{tabular}

*1) Pd crystallite size $(\AA)=10,000 / 2 \mathrm{~S}$ (where $\mathrm{S}$ represents Pd surface area $\mathrm{m}^{2} / \mathrm{g} \mathrm{Pd}$ )

*2) Fractional surface coverage of carrier with Pd (\%)

$$
=\frac{1 / 4 \times \text { Pd S.A. }\left(\mathrm{m}^{2} / \mathrm{g} \text { cat. }\right)}{\mathrm{Al}_{2} \mathrm{O}_{3} \mathrm{~S} \cdot \mathrm{A} \cdot\left(\mathrm{m}^{2} / \mathrm{g}\right)} \times 100
$$

$(1 / 4 \times \mathrm{Pd}$ S.A. $=$ Section area of $\mathrm{Pd}$ crystallite $)$

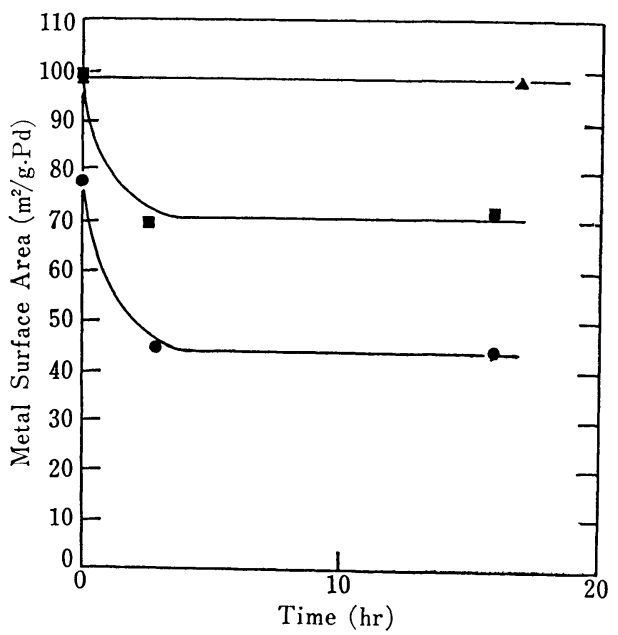

Catalyst : $\mathrm{Pd}-\mathrm{Al}_{2} \mathrm{O}_{3}$ (IV)

$\triangle \operatorname{Pd} 0.1 \mathrm{wt} \%, \square \operatorname{Pd} 0.3 \mathrm{wt} \%$,

Thermal aging : $600^{\circ} \mathrm{C}$ in vacuum

Fig. 3 Effect of Palladium Content on Sintering

lite growth (Table 5), as most of the decrease in the surface area may be accounted for in terms of thermal sintering. However, the pronounced crys- tallite growth of $\mathrm{Pd}$ was observed in the presence of acetic acid/oxygen mixtures at considerably lower temperatures. To obtain further information on the role of the support in chemical sintering, catalyst samples on different supports were exposed to acetic acid/oxygen environments (Table 6). The $\mathrm{SiO}_{2}$ supported catalyst retained its $\mathrm{Pd}$-metal dispersion while the $\mathrm{Al}_{2} \mathrm{O}_{3}$-supported samples sintered readily by comparison.

\section{Discussion}

For the interpretation of the experimental results on thermal sintering in vacuum, two aspects must be considered. One deals with the role of the support in controlling the initial dispersion of $\mathrm{Pd}$, the other concerns with the influence of the support on crystallite growth by thermal aging in vacuum.

By comparing the initial surface area of the $\mathrm{Al}_{2} \mathrm{O}_{3}$-supported samples and that of the $\mathrm{SiO}_{2}$ - or $\mathrm{SiO}_{2} / \mathrm{Al}_{2} \mathrm{O}_{3}$-supported catalysts, it is noted that the latter materials yield much lower Pd-dispersion, an effect noted previously?),17). The cause for this 
Table 3 Effect of Carrier Type and Palladium Concentration of Thermal Sintering at $600^{\circ} \mathrm{C}$

\begin{tabular}{|c|c|c|c|c|c|c|c|}
\hline \multicolumn{3}{|c|}{ Carrier } & \multirow{2}{*}{$\begin{array}{l}\text { Pd Content } \\
(\mathrm{wt} \%)\end{array}$} & \multirow{2}{*}{$\begin{array}{c}\text { Treatment } \\
(\mathrm{hr})\end{array}$} & \multirow{2}{*}{$\begin{array}{c}\text { Pd S.A. } \\
\left(\mathrm{m}^{2} / \mathrm{g}\right)\end{array}$} & \multirow{2}{*}{$\begin{array}{c}\text { Pd Crystal } \\
\text { Size }(\AA)\end{array}$} & \multirow{2}{*}{$\begin{array}{l}\text { Fractional Surface } \\
\text { Coverage of Carrier } \\
\text { with Pd }(\%)^{* 2)}\end{array}$} \\
\hline No. & $\begin{array}{l}\text { S.A. } \\
\left(\mathrm{m}^{2} / \mathrm{g}\right)\end{array}$ & $\begin{array}{c}\text { Pore Size*1) } \\
(\AA)\end{array}$ & & & & & \\
\hline $\mathrm{SiO}_{2}(\mathrm{I})$ & 96 & $30 \sim 300$ & 1.0 & $\begin{array}{l}0 \\
4.5 \\
11\end{array}$ & $\begin{array}{l}52 \\
35 \\
24\end{array}$ & $\begin{array}{r}96 \\
143 \\
208\end{array}$ & $\begin{array}{l}0.14 \\
0.093 \\
0.063\end{array}$ \\
\hline $\mathrm{SiO}_{2}(\mathrm{II})$ & 105 & $100 \sim 300$ & 1.0 & $\begin{array}{r}0 \\
3 \\
22\end{array}$ & $\begin{array}{l}55 \\
27 \\
26\end{array}$ & $\begin{array}{r}91 \\
185 \\
192\end{array}$ & $\begin{array}{l}0.16 \\
0.075 \\
0.075\end{array}$ \\
\hline \multirow[t]{2}{*}{$\mathrm{SiO}_{2}(\mathrm{III})$} & \multirow[t]{2}{*}{25} & \multirow[t]{2}{*}{$100 \sim 700$} & 0.5 & $\begin{array}{r}0 \\
2 \\
16\end{array}$ & $\begin{array}{l}32 \\
27 \\
25\end{array}$ & $\begin{array}{l}156 \\
185 \\
200\end{array}$ & $\begin{array}{l}0.16 \\
0.14 \\
0.125\end{array}$ \\
\hline & & & 1.0 & $\begin{array}{r}0 \\
16\end{array}$ & $\begin{array}{l}23 \\
15\end{array}$ & $\begin{array}{l}218 \\
334\end{array}$ & $\begin{array}{l}0.23 \\
0.15\end{array}$ \\
\hline $\mathrm{SiO}_{2} \cdot \mathrm{Al}_{2} \mathrm{O}_{3}$ & 250 & broad & 1.0 & $\begin{array}{c}0 \\
21.5\end{array}$ & $\begin{array}{l}15 \\
14\end{array}$ & $\begin{array}{l}334 \\
356\end{array}$ & $\begin{array}{l}0.015 \\
0.014\end{array}$ \\
\hline
\end{tabular}

*1) $80 \%$ of total pore volume of a carrier.

Pd crystallite size $(\AA)=10,000 / 2 S$ (where $S$ represent Pd surface area $\mathrm{m}^{2} / \mathrm{g}_{\mathrm{Pd}}$ )

*2) Fractional surface coverage of carrier with $\mathrm{Pd}(\%)$ given in Table 2.

Table 4 Number of Palladium Crystallites and Interparticle Distance*

\begin{tabular}{|c|c|c|c|c|c|}
\hline \multicolumn{2}{|c|}{ Carrier } & \multirow{2}{*}{$\begin{array}{l}\text { Pd Content } \\
(w t \%)\end{array}$} & \multirow{2}{*}{$\begin{array}{c}\text { Mean Crystallite } \\
\text { Size }(\AA)\end{array}$} & \multirow{2}{*}{$\begin{array}{l}\text { Number of } \\
\text { Crystallites } \\
\text { per } g \cdot c a t\end{array}$} & \multirow{2}{*}{$\begin{array}{c}\text { Critical Distance of } \\
\text { Crystallites }(\AA)\end{array}$} \\
\hline No. & $\left(\mathrm{m}^{2} / \mathrm{g}\right)$ & & & & \\
\hline (I) & 150 & 1.0 & 56 & 9.0 & 1,290 \\
\hline (II) & 82 & $\begin{array}{l}5.0 \\
1.0\end{array}$ & $\begin{array}{r}147.5 \\
71.5\end{array}$ & $\begin{array}{l}2.5 \\
4.4\end{array}$ & $\begin{array}{l}1,820 \\
1,370\end{array}$ \\
\hline (III) & 23 & 1.0 & 93 & 2.0 & 1,080 \\
\hline (IV) & 9 & $\begin{array}{l}0.3 \\
1.0\end{array}$ & $\begin{array}{l}92.5 \\
139\end{array}$ & $\begin{array}{l}0.63 \\
0.59\end{array}$ & $\begin{array}{l}1,300 \\
1,240\end{array}$ \\
\hline$(\mathrm{V})$ & 9 & $\begin{array}{l}0.1 \\
0.3 \\
1.0\end{array}$ & $\begin{array}{l}50.5 \\
68 \\
114\end{array}$ & $\begin{array}{l}1.23 \\
1.59 \\
1.07\end{array}$ & $\begin{array}{l}860 \\
752 \\
920\end{array}$ \\
\hline$(\mathrm{VI})$ & 8 & $\begin{array}{l}0.3 \\
1.0\end{array}$ & $\begin{array}{c}79.5 \\
173\end{array}$ & $\begin{array}{l}1.00 \\
0.37\end{array}$ & $\begin{array}{r}880 \\
1,490\end{array}$ \\
\hline
\end{tabular}

* Average equilibrium distance between palladium crystallites after sintering.

difference does not appear to be associated with the pore structure or surface area of the supports. Rather it could be the result of the chemical interaction between the $\mathrm{Pd}$-salt and the support and the bonding of the metal after reduction. In studies reported by Echigoya et al., ${ }^{17}$ ) the mass of $\mathrm{Pd}$ salt adsorbed by various $\mathrm{Al}_{2} \mathrm{O}_{3}, \mathrm{SiO}_{2}$ and $\mathrm{SiO}_{2} /$ $\mathrm{Al}_{2} \mathrm{O}_{3}$ supports was found to be a function of the type of Pd-complex salt used. These authors found that $\mathrm{Pd}$ complexed as an anion, such as in $\left(\mathrm{PdCl}_{4}\right)^{2-}$, shows little adsorptive affinity for $\mathrm{SiO}_{2}$ or $\mathrm{SiO}_{2} /$ $\mathrm{Al}_{2} \mathrm{O}_{3}$ in comparison with $\mathrm{Al}_{2} \mathrm{O}_{3}$; on the other hand, when $\mathrm{Pd}$ is present in the cationic form $\left(\left[\mathrm{Pd}\left(\mathrm{NH}_{3}\right)_{\mathrm{m}}\right]^{2+}\right)$, just the opposite effect is observed.

$\mathrm{Pd}$ crystallites on $\mathrm{SiO}_{2}$ and $\mathrm{SiO}_{2} / \mathrm{Al}_{2} \mathrm{O}_{3}$ were less resistant to sintering than on $\mathrm{Al}_{2} \mathrm{O}_{3}$. Weller et al. ${ }^{15}$ ) observed a similar phenomenon on supported platinum catalysts. These results suggest that interaction takes place between alumina and the metal (or an oxide coated metal crystallite), similar to the interaction between $\mathrm{Pd}$ salt and alumina described above. In fact, some workers have indicated the evidence of the formation of a Pt-alumina complex which stabilized the platinum crystallites $^{15), 16)}$.

The sintering curve of $\mathrm{Pd} / \mathrm{Al}_{2} \mathrm{O}_{3}$ catalysts (Figs. $\mathbf{1}$ and 3) can be divided into two stages, i.e., labile state and steady state. The rate of sintering during the labile state and the existence of a limiting crystallite size beyond which no further change occurs in metal surface area appear to be related to the fractional surface coverage of the carrier 


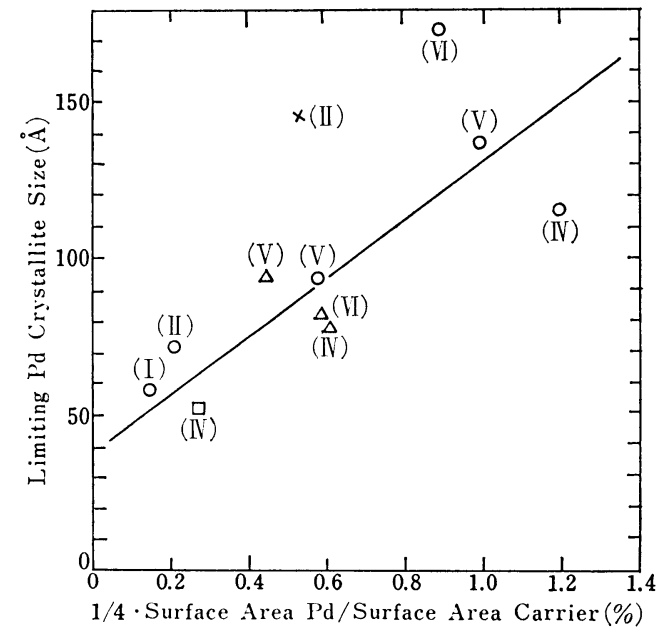

Physical data on supports given in Table 2 Catalyst : Pd content (wt \%)

$\square 0.1, \triangle 0.3, \bigcirc 1.0, \times 5.0$

Fig. 4 Effect of Fractional Surface Coverage of Carrier with Palladium on Sintering

Table 5 Dispersion Stability of $\mathrm{Pd} / \mathrm{Al}_{2} \mathrm{O}_{3}$ Catalysts in Reactive Environment

\begin{tabular}{|c|c|c|c|c|c|}
\hline \multirow[b]{2}{*}{ Catalyst } & \multicolumn{4}{|c|}{ Exposure } & \multirow{2}{*}{\begin{tabular}{|c|}
$\mathrm{Pd}$ \\
Surface \\
Area \\
$\left(\mathrm{m}^{2} / \mathrm{g}\right.$ \\
$\mathrm{Pd})$
\end{tabular}} \\
\hline & Gas & \begin{tabular}{|c|} 
Pressure \\
(torr)
\end{tabular} & $\begin{array}{l}\text { Temp. } \\
\left({ }^{\circ} \mathrm{C}\right)\end{array}$ & $\underset{(\mathrm{hr})}{\operatorname{Time}}$ & \\
\hline $\begin{array}{c}\mathrm{Pd}(1.0 \mathrm{wt} \%) / \\
\theta-\mathrm{Al}_{2} \mathrm{O}_{3}\end{array}$ & $\begin{array}{l}\overline{-} \\
\overline{\mathrm{H}_{2}} \\
\mathrm{O}_{2}\end{array}$ & $\begin{array}{c}<10^{-6} \\
<10^{-6} \\
380 \\
40\end{array}$ & $\begin{array}{l}600 \\
600 \\
600\end{array}$ & $\begin{array}{l}- \\
3 \\
3 \\
3\end{array}$ & $\begin{array}{l}92 \pm 3 * 1) \\
83 \pm 3 \\
95 \pm 5 \\
90 \pm 3 * 2)\end{array}$ \\
\hline $\begin{array}{c}\mathrm{Pd}(1.0 \mathrm{wt} \%) / \\
\alpha-\mathrm{Al}_{2} \mathrm{O}_{3}\end{array}$ & $\begin{array}{c}\overline{-} \\
\overline{\bar{H}} \\
\overline{\mathrm{H}}_{2} \\
\mathrm{O}_{2} \\
\mathrm{AcOH}^{2)} \\
\mathrm{Air}\end{array}$ & $\mid \begin{array}{c}<10^{-6} \\
<10^{-6} \\
<10^{-6} \\
380 \\
380 \\
115 / 645\end{array}$ & $\begin{array}{l}600 \\
600 \\
600 \\
500 \\
200\end{array}$ & $\begin{array}{r}- \\
3 \\
16 \\
3 \\
4 \\
22\end{array}$ & $\begin{array}{r}120 \pm 4 \\
71 \pm 2 \\
62 \pm 2 \\
78 \pm 3 \\
70 \pm 3 \\
18 \pm 3\end{array}$ \\
\hline
\end{tabular}

*1) Initial surface area.

*2) Following the exposure to oxygen or $\mathrm{AcOH} /$ air the sample was exposed to hydrogen at 200 torr and $200^{\circ} \mathrm{C}$, for $2.5 \mathrm{hr}$, then to vacuume $\left(\mathrm{P}<10^{-6}\right.$ torr $)$ at $300^{\circ} \mathrm{C}$ for $12 \mathrm{hrs}$. ( $\left.\mathrm{AcOH}=\mathrm{CH}_{3} \mathrm{COOH}\right)$.

with $\mathrm{Pd}(\mathrm{FSC})$, i.e., the surface area ratio of $\mathrm{Pd}$ to the support material (Table 2). The small crystallites can be stabilized at low FSG as they occur on a carrier having high surface area and low Pd content (Fig. 4). The distance between the particles at steady state was estimated from the average metal crystallite size computed on the basis of cubic shape and of contact with the carrier at one face. The results of these calculations (Table 4) indicate that on alumina the Pd crystallites cease to grow when the distance between particles reaches from 750 to $1,500 \AA$.

Regarding the effect of chemically reactive atmospheres on Pd sintering, a remarkable crystal-
Table 6 Effect of Catalyst Support on Palladium Sintering during Exposure to Acetic Acid/ Oxygen Mixtures*1)

\begin{tabular}{l|c|c|c|c}
\hline \multirow{2}{*}{ Catalyst } & \multicolumn{2}{|c|}{ Exposure } & \multicolumn{2}{c}{$\begin{array}{c}\text { Pd Surface Area } \\
\left(\mathrm{m}^{2} / \mathrm{g} \mathrm{Pd}\right)\end{array}$} \\
\cline { 2 - 3 } & $\begin{array}{c}\text { Temp. } \\
\left({ }^{\circ} \mathrm{C}\right)\end{array}$ & $\begin{array}{c}\text { Time } \\
(\mathrm{hr})\end{array}$ & Initial & Final \\
\hline $\mathrm{Pd}(1.0 \mathrm{wt} \%) / \mathrm{Al}_{2} \mathrm{O}_{3}{ }^{* 2)}$ & 200 & 22 & $120 \pm 4$ & $18 \pm 3$ \\
$\mathrm{Pd}(1.0 \mathrm{wt} \%) / \mathrm{Al}_{3} \mathrm{O}_{3}$ & 135 & 16 & $120 \pm 4$ & $39 \pm 3$ \\
$\mathrm{Pd}(1.0 \mathrm{wt} \%) / \mathrm{SiO}_{2}$ & 135 & 16 & $52 \pm 2$ & $55 \pm 2$ \\
\hline${ }^{* 1)}$ & 115 torr $\mathrm{CH}_{3} \mathrm{COOH}, 130$ torr $\mathrm{O}_{2}, 515$ torr $\mathrm{N}_{2}$. \\
$\left.*_{2}\right)$ & $\alpha-\mathrm{Al}_{2} \mathrm{O}_{3}$, source as in Table 5.
\end{tabular}

lite growth of $\mathrm{Pd}$ was observed in the presence of acetic acid/oxygen mixtures at considerably lower temperatures while the degree of crystallite growth of $\mathrm{Pd}$ in hydrogen or oxygen was similar to that in vacuum. The aggregation of $\mathrm{Pd}$ in acetic acid/ oxygen environments may result from the formation of $\mathrm{Pd}\left(\mathrm{OCOCH}_{3}\right)_{2}$ and its migration, as reported previously ${ }^{21)}$. The cause for the difference in the degree of $\mathrm{Pd}$ aggregation between the $\mathrm{SiO}_{2}$ supported catalyst and the $\mathrm{Al}_{2} \mathrm{O}_{3}$-supported catalysts (Table 6) has not been established. It may point to the existence of some $\mathrm{Pd}$-cations on the surface of alumina supports and predominantly Pd-metal on the surface of silica supports.

\section{References}

1) Benson, J. E., Swang, H. S., Boudart, M., J. Catal., 30, 146 (1973).

2) Wentrcek, P., Kimoto, K., Wise, H., ibid., 33, 279 (1973).

3) Wentrcek, P., Wise, H., ibid., 36, 247 (1975).

4) Adler, S. F., Kearney, J. J., J. Phys. Chem., 64, 208 (1960).

5) Mills, G. A., Weller, S., Cornelius, E. B., Proc. 2nd Int. Cong. Catal., 2221 (1960) Paris.

6) Herrmann, R. A., Alder, S. F., Goldstein, M. S., DeBaun, R. M. J. Phys. Chem., 65, 2189 (1961).

7) Gruber, H. L., ibid., 66, 48 (1962).

8) Johnson, M. F. L. Keith, G. D., ibid., 67, 200 (1963).

9) Maat, H. J., Moscon, L., Proc. 3rd Int. Cong. Catal., 1277 (1965).

10) Dorling, T. A., Moss, R. L., J. Catal., 5, 111 (1966).

11) Dorling, T. A., Moss, R. L., ibid., 7, 378 (1967).

12) Dorling, T. A., Lynch, B. W. J., Moss, R. L., ibid., 20, 190 (1971).

13) Ruckenstein, E., Pulvermacher, B., ibid., 29, 224 (1973).

14) Flynn, P. G., Wanke, S. E., Third North American Meeting, Catalysis Society, Paper No. 25 February 4 6, (1974).

15) Weller, W. S., Montagna, A. A., J. Catal., 20, 394 (1971).

16) McHenry, K. W., Bertolacini, R. J., Brennan, M. H., Wilson, L. J., Seeling, H. S., Actes Cong. Int. Catal., 2nd (1960).

17) Echigoya, E., Furuoya, I., Morikawa, K., Kogyo Kagaku Zasshi, 71, 1768 (1968). 
18) Shirasaki, T., Furuoya, I., ibid., 71, 1774 (1968).

19) Furuoya, I., Shirasaki, T., ibid., 72, 1223 (1969).

20) Furuoya, I., Shirasaki, T., Echigoya, E., Morikawa,
K., ibid., 72, 1431 (1969).

21) Nakamura, S., Yasui, T., J. Catal., 23, 315 (1971).

要 旨

\title{
担持パラジゥム結晶粒子の熱安定性
}

\author{
中 村 征四郎*1), Henry Wise*2)
}

含浸法により調製した Pd 触媒に関し，真空ならびに種々の ガスふん囲気下に护ける Pd 結晶粒子の熱安定性について検討 した。Pd の結晶粒子径は CO 滴定法により測定した ${ }^{2), 3) 。 ~}$

\section{（1）真空下での Pd の熱安定性}

調製した $\mathrm{Pd}$ の分散性は担体の種類により異なり, $\mathrm{Al}_{2} \mathrm{O}_{3}>$ $\mathrm{SiO}_{2}, \quad \mathrm{SiO}_{2} \cdot \mathrm{Al}_{2} \mathrm{O}_{3}$ であった。また，熱安定性に関しても， $\mathrm{Al}_{2} \mathrm{O}_{3}$ に担持させた $\mathrm{Pd}$ がとくにすぐれていた（Tables 2, 3 との比較)。

表面積ならびに細孔径分布の異なる 5 種の $\mathrm{Al}_{2} \mathrm{O}_{3}$ 担体 (Table 1) について，Pd を担体に対し 0.1 $5 \mathrm{wt} \%$ 担持させ， それらの熱安定性を比較した(Figs. 1 3)。いずれの触媒も熱 処理の初期に Pd の結晶粒子の成長がおこるが，数時間後に成 長はとまり，Pd 結晶粒子は一定の值 $\left(D_{1 \mathrm{imit} . \mathrm{Pd}}\right)$ となって 安定化した。各触媒について, Pd の結晶粒子径から担体表面 上の $\mathrm{Pd}$ の被覆率 (触媒 $\mathrm{g}$ 当りの $\mathrm{Pd}$ 結晶粒子の総断面積/触 媒 $\mathrm{g}$ 当りの担体の表面積 $\times 100)$ を算出した結果，Pd の被覆率 と $D_{1 \mathrm{mit}} \mathrm{Pd}$ との間に直線関係が成立し (Fig. 4), Pd の被 覆率の小さい触媒ほど $D_{1 \mathrm{mit}}$. Pd は小となることが示唆され た。これより, 熱安定性のよい触媒をつくるには, Pd の被覆

*1) (株)クラレ中央研究所 (710 岡山県合敷市酒津 2045)
率を小さくする，換言すれば，表面積の大きい担体を用いるま たは Pd の担持量を少なくすることが必要であることがわか る。Pd の結晶粒子の成長がとまり, 安定化した時点での結晶 粒子の間隔は 750〜1,500 と算出された（Table 4)。

（2）種々のガスふん囲気下に扩梳 Pd の熱安定性

酸素, 水素ならびに (酢酸+酸素) の 3 種のガスについて, それぞれの ガスらん囲気下で $\mathrm{Pd} / \mathrm{Al}_{2} \mathrm{O}_{3}$ 触媒を加熱処理し， Pd 結晶粒子の成長の度合を調べた。酸素および水素のガスふ 几囲気中での熱安定性 $\left(600^{\circ} \mathrm{C}\right)$ は, 真空下での場合とほぼ同 椂であるのに対し，(酢酸十酸素）ガスで熱処理した場合には， 低温下 $\left(200^{\circ} \mathrm{C}\right)$ において Pd 結晶粒子の顕著な成長が認めら れた (Table 5)。このような処理条件下では Pd 触媒上に Pd $\left(\mathrm{OCOCH}_{3}\right)_{2}$ が生成すること ${ }^{21)}$ から，この場合の $\mathrm{Pd}$ 結晶粒 子の成長機構は真空下の場合と異なり, $\mathrm{Pd}\left(\mathrm{OCOCH}_{3}\right)_{2}$ を経 由しておこるもの 21) と推定された。上記と同様の処理条件 (た だし， $\left.135^{\circ} \mathrm{C}\right)$ で $\mathrm{Pd} / \mathrm{SiO}_{2}$ と $\mathrm{Pd} / \mathrm{Al}_{2} \mathrm{O}_{3}$ の熱安定性を比較し たが， $\mathrm{SiO}_{2}$ 担体上では $\mathrm{Al}_{2} \mathrm{O}_{3}$ 担体の場合にみられるような Pd 結晶粒子の成長は掞こらなかった（Table 5)。この相異は 現在明らかでないが，打そらくは， $\mathrm{SiO}_{2}$ 担体上では $\mathrm{Pd}^{2+}$ が生 成し難いことによるものであろう。

\section{Keyword}

Dispersion, Palladium, Sintering 